\title{
THE STUDY OF ACTIVITIES IN CLASSIC HOUSEHOLDS
}

\section{Two case studies from Coba and Teotihuacan}

\author{
Linda Manzanilla and Luis Barba \\ Instituto de Investigaciones Antropológicas, UNAM, Ciudad Universitaria, México, D.F. 04510
}

\begin{abstract}
Mesoamerican household sites were often deserted gradually, leaving very little de facto refuse for analysis. Starting with archaeological and paleobiological distribution patterns, this study adds a new dimension to the spatial study of two Classic households by plotting chemical concentrations in probable activity areas.
\end{abstract}

The study of activity areas and domestic structures has become a fertile field of archaeological research. Yet, in some cases, this boom has also led to careless analyses of data. Though drawn from examinations of household structure, conclusions about surface distributions of artifacts and domestic mounds do not often rest on firm functional, contextual, social, or chronological evidence. Suppositions about elite versus common items, residential versus storage or cult architecture, have yet to be tested rigorously. Worse still, the archaeological literature consistently confuses refuse areas with workshops, common domestic structures with high status residences, and administrative sectors with residential areas. The result: small-scale excavations of floors have provided a voluminous number of untested and debatable hypotheses concerning household size, the degree of cooperation between families, and the developmental cycle of the unit, without, however, benefiting from a full understanding of the activity repertoire, its spatial distribution, the functions of particular structures, and the spatial limits of domestic areas.

For the past 15 years, we have excavated extensively in domestic structures from different sites of Mesoamerica, particularly in the Central Plateau (Barba et al. 1987; Manzanilla 1985, 1986a; Reyna Robles 1977; Serra 1980, 1986), but also in the Maya area (Manzanilla 1987). We have based our research on the premise that a "household is essentially an activity group" (Ashmore and Wilk 1988:3). Yet our research seems not to have reached the North American academic circle, which has concerned itself with similar issues. This lack of feedback is unfortunate, and it is with the purpose of promoting a dialogue that we write this article.

Some archaeologists (e.g., Kent 1987:2) have chosen an ethnoarchaeological approach to spatial studies, specifically with respect to the development of methods and theories for activity area research. We prefer to follow a more conventional analysis that focuses on distributional patterns of archaeological and paleobiological data (pollen, phytoliths, floral macrofossils, and faunal bone remains) in domestic structures (Binford 1983; Flannery 1976; Hill 1968). We have tried, however, to add a new dimension to such distributional maps by plotting chemical concentrations in probable activity areas (Barba 1986; Barba et al. 1987; Manzanilla 1987).

We agree with Flannery (1976:5-6) that the activity area level, which reflects repeated actions, is the minimum spatial unit of the archaeological record that has social meaning. In our research, we define activity areas from concentrations and associations of raw materials, instruments, semi-processed products, or residues on specific surfaces or in quantities that reflect particular production, consumption, storage, or evacuation processes (Manzanilla 1986a). In places of production, it is possible to distinguish between activity areas devoted to the acquisition of raw materials, such as those one would expect in mines, quarries, and extraction deposits, and the areas that are devoted to the elimination of useless parts and cores, materials, and chemical compounds. Such deposits are generally found on the outskirts of settlements and are difficult to observe in surface reconnaissance. Finally, there are production activity areas dedicated to food preparation (cleaning, grinding, cooking), manufacturing (workshops, kilns), and construction activities.

The degree of transparence of these units in the archaeological record is related not only to natural and cultural transformation processes (Rathje and Schiffer 1982; Seymour and Schiffer 1987), but to the ways in which a site was abandoned (Manzanilla 1979, 1986b:165). Sudden abandonment might be provoked by earthquakes, volcanic eruptions, floods, conflagrations, attacks, and similar events. At such time people either fled or died near their activity areas, which are of the type we call locus agendi. Examples of this type of abandonment are common in Near Eastern archaeology.

In contrast, Mesoamericanists often face cases of gradual desertion of sites, occasioned by salinization of soils, variations in river courses, desertification, changes in exchange networks, and messianic migrations. Inhabitants usually have the time to 
choose certain items for transport to the next site, depending on the portability of the object, the means of transportation, the distance to the next site, the value of the item, and the need the inhabitants have to undertake recurrent activities. Where there are floors with only a little de facto refuse, archaeologists are obliged to combine chemical, paleobotanical, and paleozoological analyses with archaeological observations; only then can activities be defined in discrete architectural units.

Use or consumption activity areas are the most common of all and may be divided according to the following criteria (Manzanilla 1979, 1986b:281).

1. Understanding family subsistence: the use of instruments, vessels, and raw materials for food consumption. Also, in other areas of domestic life, such as the reproduction of domestic plants and animals, the manufacture of clothing and the construction of houses.

2. Discerning circulation and exchange: the use of exchange and administrative devices such as shells, copper ingots, seals, coins, as well as exchange places, such as markets.

3. Investigating political organization: the use and contexts of palaces, fortresses, as well as the existence of power- and command-symbols and weapons.

4. Understanding ideology: the ritual contexts of sanctuaries, temples, tombs, and burials, and well as their offerings.

The next unit of consideration is the domestic structure. The household group is formed by those individuals who share the same space to eat, sleep, work, rest, grow, procreate, and die. The three basic criteria to define this concept are residence, shared activities, and kinship (Manzanilla 1986a:14).

When analyzing domestic constructions, it is necessary to correlate external and internal activities with their particular structures, and to evaluate their form, dimensions, construction materials, routes of access, and roofed areas. This line of analysis reveals considerable regional variation in Mesoamerica. There are sites, for example, where a single household uses more than one domestic structure and shares a large domestic territory delineated by low walls (e.g., Manzanilla 1987). In other cases, however, and specifically in Teotihuacan, central Mexico, there exist residential compounds inhabited by more than one family; these structures probably held corporate groups that shared a residence and bonds of kinship and organization.

By comparing various household structures, we may begin to consider the degree of cooperation and specialization of labor, the size of the domestic group, and differential access to different resources.

\section{CHEMICAL ANALYSIS AND ACTIVITY AREAS}

The application of chemical analysis to the study of archaeological settlements is relatively recent, having first appeared in two different fields: agronomy, where chemical analysis relates plant growth, fertility, and soil nutrients; and geochemistry, which uses chemical analysis to locate mineral deposits of economic value.

Chemical techniques were first applied to settlement archaeology during the 1940s, yet it was not until the beginning of the 1970s that Eidt (1973) began to promote the use of phosphate analysis in archaeological research. As mentioned by Goffer (1980), other authors had dealt in the meantime with ele- ments such as calcium, magnesium, copper, potassium, and zinc, and noted that substantial increases in the concentration of these elements tended to occur in inhabited areas. Such research is built on the understanding that any human settlement produces numerous alterations to the land it occupies; if not chemical, then certainly changes in topographic relief, through compaction of the ground by human feet, accumulation of ashes and debris, and differential weathering in areas covered by roofs.

Ethnoarchaeology has proven useful in determining the relationship between activities and chemical compound enrichment. Several investigations have been carried out by Luis Barba as part of a research project on activity areas in Mexico; the main goal of the project is to establish general chemical patterns of various activities, whether domestic or manufacturing. Barba's team has studied a modern house at San Vincente Xiloxochitla, Tlaxcala, two abandoned houses at Usumacinta Viejo, Chiapas, a modern house and two archaeological household units at Coba, Quintana Roo, a residential compound at Oztoyohaulco, Teotihuacan, a modern house and archaeological floors at La Florida, Zacatecas (Barba and Bello 1978; Barba and Dennis 1981: Barba et al. 1987; Barba and Manzanilla 1987a; Mejía 1987; Mejía and Barba 1988). This research included the following tests: calcium, iron, carbonates, phosphates, $\mathrm{pH}$, Munsell color, and the microscopic examination of samples.

The following observations emerged from these studies:

1. Rest or sleeping areas are found in inner rooms or, if there is only one room, opposite the fireplace. Generally these are poor in chemical compounds.

2. Areas where meals were prepared and cooked normally include hearths, which correlate with low phosphate values, color changes, and high $\mathrm{pH}$. Such areas frequently contain carbonized seeds.

3. Areas where food was consumed are rich in phosphates. Food consumption areas are located near preparation areas and contain low $\mathrm{pH}$ values. Anomalous calcium concentrations are attributable in some cases to corn bread preparation (nixtamal for tortillas).

4. Areas where animals were confined show concentrations of phosphates.

5. Areas of heavy foot traffic suffer much wear and are thus poor in chemical contents.

Chemical concentrations in such areas have distinctive characteristics; they are invisible and intangible; they represent byproducts of activities; they cannot be reused; and they show practically no vertical or horizontal displacement.

The value of chemical analyses is that they alone can reveal such patterns for the archaeologist, who will eventually benefit from Barba's growing data bank on chemical compounds in their relation to domestic and production activities. Most useful from our perspective is that Barba's information comes from differing climatic conditions prevailing in various parts of the Mexican republic.

\section{CLASSIC MAYA HOUSEHOLD UNITS AT COBA, QUINTANA ROO}

One of the first archaeological sites in which these techniques have been put into practice is Coba, excavated from 1983 to 1984, by a crew under the direction of Linda Manzanilia and 


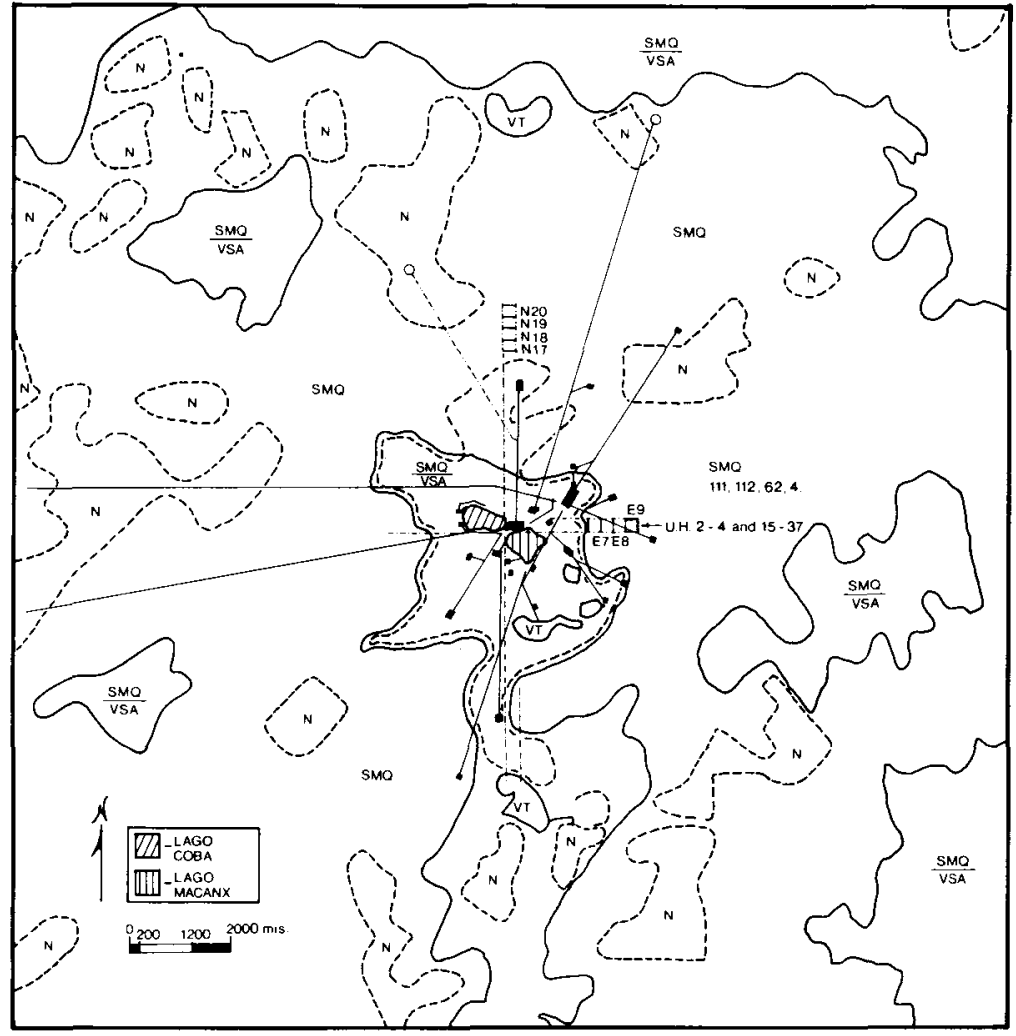

Figure 1. The site of Coba, Quintana Roo, and the location of Units 2-14 and 15-37.

Antonio Benavides (Manzanilla 1987). Two household units were studied in this project (see Figures 1 and 2), which showed that even when chemical compounds have remained in the open, under severe weathering conditions, their permanence enables us to study them today (Barba and Manzanilla 1987a).

The initial plan of reaseach included the study of stuccoed floors. During the excavation of the unit, however, only small, isolated floor fragments appeared. At first, we were puzzled by this pattern. We then noticed the apparently unrelated fact that the vegetation in the excavation area was very young, the trunks' diameters averaging below $25 \mathrm{~cm}$. This, together with the advanced state of deterioration of the limestone, suggested that some years ago there had been a fire at the site, perhaps explaining the absence of floors in the unit. We propose that the floors underwent disintegration from intense heat, forming calcium oxides and hydroxides in place of the original carbonates; most likely, these substances reacted with rain water to form bicarbonates, which would in turn have been removed from the original material and resulted in the destruction of stucco and the underlying stone. The samples obtained from the soil layer that covered the domestic unit contained the chemical compounds that had once permeated the stucco floor, as well as the remains of the floor itself. This proved to be very important, since it confirmed the durability of these compounds after approximately 1,000 years of abandonment, a fire, and exposed tropical conditions.

In addition, the distribution of chemical compounds made it possible to determine differences in the function of certain domestic structures. For example, discrepancies in carbonate distribution could be detected; in Unit 2-14 the maximum val- ues occurred in two structures, while in Unit 15-37 the highest figures belonged to particular activity areas (see Figure 3). Phosphates were more abundant in Unit 15-37, suggesting activities related to food preparation and consumption.

The final conclusion to be drawn from this work is the observation that Unit 2-14 had two stuccoed structures (E4 and E8), which were probably devoted to living or sleeping, along with a possible sanctuary (E12) located to the east of the central patio (a third structure), as well as two small kitchens (ES and E8) located to the northwest. It had also a refuse sector between E5 and E8, and a domestic orchard to the south of the courtyard, suggesting a planned Peten-like pattern. This unit contained the biggest and most important construction offerings, including Lucha Incised vases. Most sherds dated to the final years of the Middle Classic, although Late Classic sherds were found on the surface.

In contrast, Unit 15-37 had wattle-and-daub structures with no carbonates and a different distribution of buildings. The highest amount of phosphates appeared in the perimeter of a central, ill-defined space. Five wattle-and-daub structures were built around this open area, where food preparation, including grinding, cooking, and food consumption probably took place. Three other sectors of the domestic space included living quarters of rectangular shape: E15, E32, and E26. In addition there were five circular buildings (E18, E22, E24, E34, and E37) and one square structure (E19) that was probably devoted to storage and subsidiary activities (Manzanilla 1987).

The two units touched each other and were partially contemporaneous. They had a shared route of access, a similar direction of circulation (north-south), and similar ceramic types. Yet 


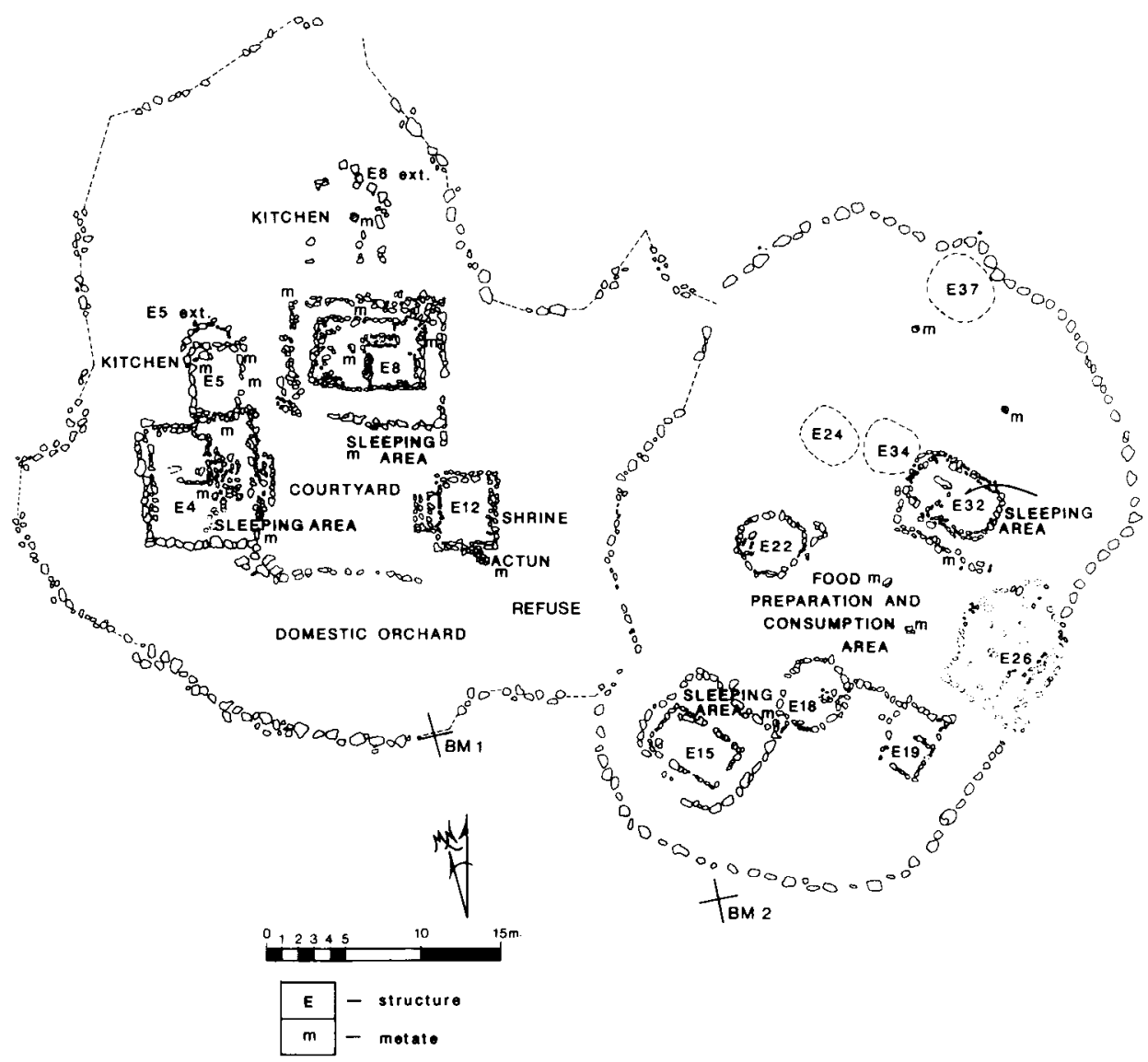

Figure 2. Domestic Units 2-14 and 15-37, with activity areas indicated.

we believe that sometime between A.D. 600 and 700, an extended family constructed Unit 2-14. When this family's offspring married, Unit 15-37 was added to satisfy their needs. Both units probably participated in domestic cults and other special activities; in all probability, food and consumption for both units occurred in Unit 15-37, as reflected in its higher phosphate values.

The "family growth" hypothesis (see Tourtellot 1988) may be usefully applied to our Coba units. Yet, following Tourtellot, one implication of the hypothesis is that "units occupied for a longer time should have more dwellings than units occupied for a shorter time" (p. 104). Nevertheless, we propose that neighboring and attached units could be related to one another and that the unit with more structures (Unit 15-37) could be an extension of the "founder's" unit (2-14).

In general, Structures 4 and 8 (Unit 2-14) better fit the pattern observed by Tourtellot at Seibal (Tourtellot 1988:101-102), where a dwelling typically has a floor area above $23 \mathrm{~m}^{2}$ (Structures 4 and 8 at Coba have $22 \mathrm{~m}^{2}$ and $24 \mathrm{~m}^{2}$, respectively), a rectangular plan, an orientation rightward of the cardinal points, a centered location on the side of a patio, midden deposits to three sides and to the rear of the structures. Hearths, metates, and manos are usually found in kitchens nearby. Furthermore, in the dependent unit (15-37), the two rectangular constructions on platforms, Structures 15 and 32, have floor areas ( 15 and $16.5 \mathrm{~m}^{2}$, respectively) that do not reach the minimum stipulated for dwellings at Seibal.

It is also noteworthy Tourtellot's (1988) observation fits our data: "The northern and western positions in the patios of units are arguably the most favored positions for dwellings, and the eastern the least favored" (p. 112). Structures 4 and 8 are located to the west and north of the patio, and the eastern sector is occupied by a sanctuary. In addition, Unit 2-14 seems to belong to the group that has a pair of Class $\mathrm{K}$ founder's dwellings, which in Seibal attain 13\% of the total (Tourtellot 1988:113).

\section{A RESIDENTIAL STRUCTURE AT TEOTIHUACAN}

Teotihuacan was the first urban development in the Central Mexican Plateau, with dates from approximately 100 B.c. to A.D. 750 . The city covers $20 \mathrm{~km}^{2}$ of densely constructed space and displays a regular grid, specialized manufacturing sectors, a ceremonial and administrative core on the sides of the Avenue of the Dead (the city's main axis). It also has various suggestions of urban planning, including well-coordinated systems of drainage and water supply that rerouted the San Juan River to conform to the city's grid (Millon 1973).

A great proportion of the city's population probably lived in residential compounds surrounded by walls, which secluded domestic life from other city activities. These multi-room compounds, inhabited by several families, are believed to represent corporate groups linked by kinship, residence, and occupation (Millon 1973). Nevertheless, until the 1980s, residential compounds, such as Tetitla, Yayahuala, Atetelco, La Ventilla, and Tlamimilolpa, were excavated only to obtain architectural and skeletal data, and not to answer such questions as: How many 


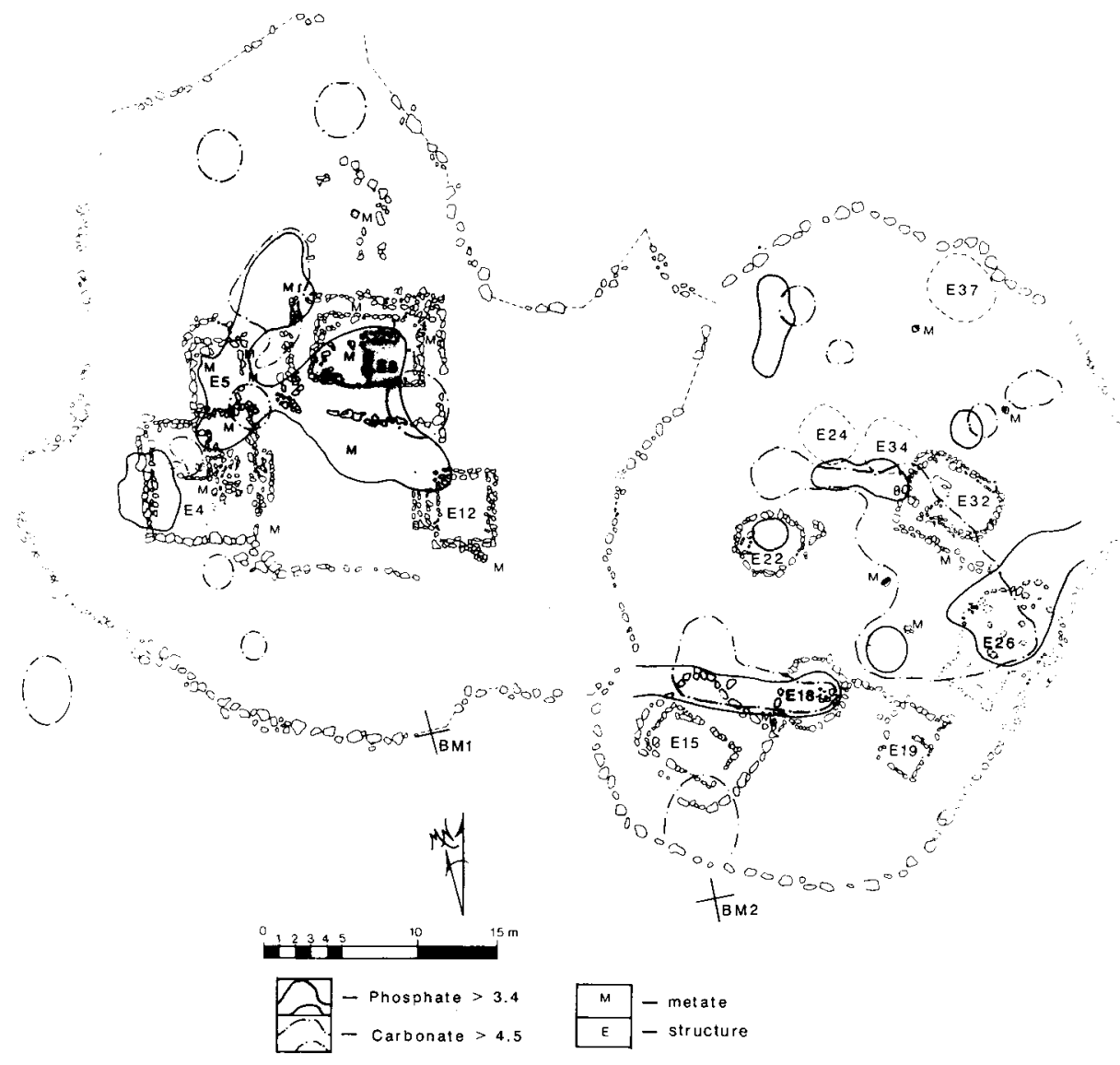

Figure 3. Chemical concentrations in Units 2-14 and 15-37.

families dwelt in each compound? What domestic activities have survived in the archaeological record, and what is their room-by-room distribution? Are there any data that support the idea of occupations carried out by the group as a whole?

Directed by Linda Manzanilla, the interdisciplinary project known as the "Old City of Teotihuacan: First Phases of Urban Development" was designed to locate and excavate residential compounds in the Oztoyohualco region, a sector on the northwestern fringe of the city, that Millon identified as the center of the earliest urban settlement. Our research focused not only on activity area research, but on the detection of centralized storage in the hands of the Teotihuacan priesthood.

We decided to excavate an area between two of the "threetemple" complexes in Millon's N6W3 square which promised to have several residential compounds. After an intensive survey that included the use of low-scale aerial photographs taken from a helium balloon, as well as with topographical, geophysical, geochemical, and archaeological distribution maps following a $4 \mathrm{~m}$ grid, we detected a series of structures, of which one (see Figure 4), a large low mound to the northeast of the southern three-temple complex, had the characteristics we were looking for. In 1986 we began extensive excavations aimed at assessing particular activities in the rooms of this building (Barba and Manzanilla 1987b).

The structure, measuring about $550 \mathrm{~m}^{2}$ in area, a fifth of Tetitla's surface, was dated to the Xolalpan phase (about A.D. 550-660), a period of reoccupation in the Oztoyohualco sector that resulted from demographic increase in the city. Yet, under- neath the Xolalpan structure lay only sterile tuff, just above the pyroclastic flow that underlies Teotihuacan. Thus, in this sector there were no data supporting the "earliest northwestern urban center" hypothesis. Nevertheless, the activity area data were rich and provided new methodological insights into the problem of gradual abandonment.

The Xolalpan residential structure was deserted over time, allowing the residents to remove many of the artifacts. In certain rooms we found only traces of de facto refuse. We also found that the stucco floors were scrupulously swept clean, removing most of the macroscopic remains. As a consequence, we adopted a strategy that took into consideration chemical traces in the stucco floors, as well as microscopic pollen and phytolithic evidence.

During the excavation process, we isolated discrete distributions that might conceivably represent activity areas. These were normally delineated structurally, either as offering or burial cavities excavated in the stucco floors, or associations of storage vessels, or even concentrations of artifacts or faunal remains in the corners of the rooms. The rest of the domestic floor space was sampled by collecting earth from directly over the floor in each $\mathrm{m}^{2}$; these samples were then submitted to pollen, phytolith, and macrofossil analysis. The seeds and other floral remains recovered from each room were then contrasted with archaeological and faunal data.

When the excavation and recording were over, we used a 5 $\mathrm{cm}$ drill to take chemical samples from each $\mathrm{m}^{2}$ of stucco floor. Luis Barba (1986) showed from ethnographic, as well as 


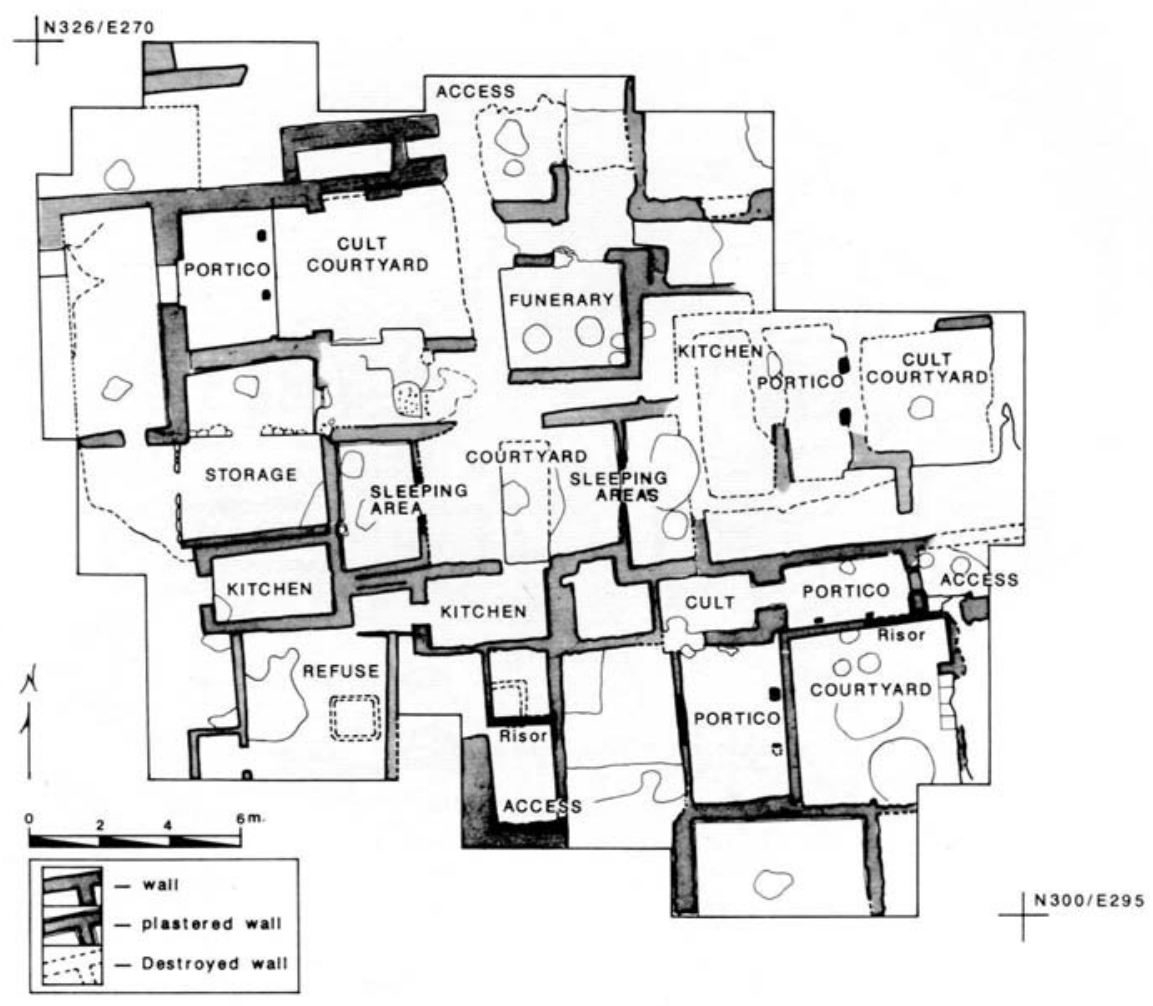

Figure 4. A Teotihuacan residential compound and its activity areas.

archaeological, evidence that stucco floors trap chemical compounds derived from specific activities; in particular, the amount of calcium, carbonate, and porosity of the floor favor the preservation of chemicals. He also demonstrated that specific chemical tests could be done where there is the suspicion of specific activities related to these residues. Iron concentrations, for example, could be derived from Agave processing or from butchering sites.

At present, the results of such analyses are incomplete. We have completed investigations of the central portion of the compound, but samples from peripheral rooms are still being processed.

\section{Food Processing and Consumption}

We have located two discrete sectors where food was prepared and consumed: one (Room C3-4) was recognized by dark red stains on the floor, a reduction of carbonate values, and a considerable increase in the $\mathrm{pH}$, in this case surrounded by a semicircular band of phosphates. From this we concluded that a cooking fire had been lit in the western portion of the room, inside a ceramic brazier placed on top of the darkest stain. The fire resulted in a loss of carbonates and produced an oxidation of iron minerals, leaving a dark red spot. The ash byproducts of the combustion augmented the $\mathrm{pH}$ in the stain zone. We also believe the phosphate band was a major area of food consumption, a conclusion supported by the fact that a grinding instrument lay lear the dark stain, in close proximity to a small storage room (C5). In the western sector of Room C3-4 we also found charred seeds of legumes and Chenopodium.

The eastern sector of C3-4 was a transit zone, with some or- ganic debris left by sweeping; it included rabbit bones, gastropod shells, a charred Agave spine, as well as Panicum and charred maize remains. Its door gave access to a small service courtyard, with northern drainage, that received refuse from the consumption area. Ashes swept across the courtyard resulted in a band of increased $\mathrm{pH}$, as well as occasional turkey remains. Near the drainage, where virtually all of the refuse was concentrated, lay an area with a high phosphate value (Figure 5).

The other zone where cooking had taken place was located to the northeast, in a L-shaped corridor. This area was detected also by a change of color, an increase in $\mathrm{pH}$, and a concentration of phosphate. Near this area were two small cavities, one of which contained an offering consisting of Gramineae, along with an extremely high percentage of maize. The other cavity had a child burial nestled within a vessel. Surrounding this cooking zone were charred prickly pear seeds and remains of rabbit and hare.

\section{Storage}

Two storage sectors were found, one (Room C5) directly to the west of the consumption areas. Besides containing a storage vessel, Room $\mathrm{C} 5$ yielded several plant macrofossils dominated by charred maize and noncarbonized Leguminoseae, together with charred Chenopodium, cactus, Euphorbia, and noncarbonized Ipomoea. A quantity of Casimiroa pollen $(95 \%)$ indicates that a mass of Casimiroa flowers had been stored there. In prehistoric times this plant had medicinal uses, and early chroniclers write of its hypnotic and soporific effects. We should also say that the floor surface showed no intense activity, as could be seen from the mean chemical values. The only anomaly $-a$ 

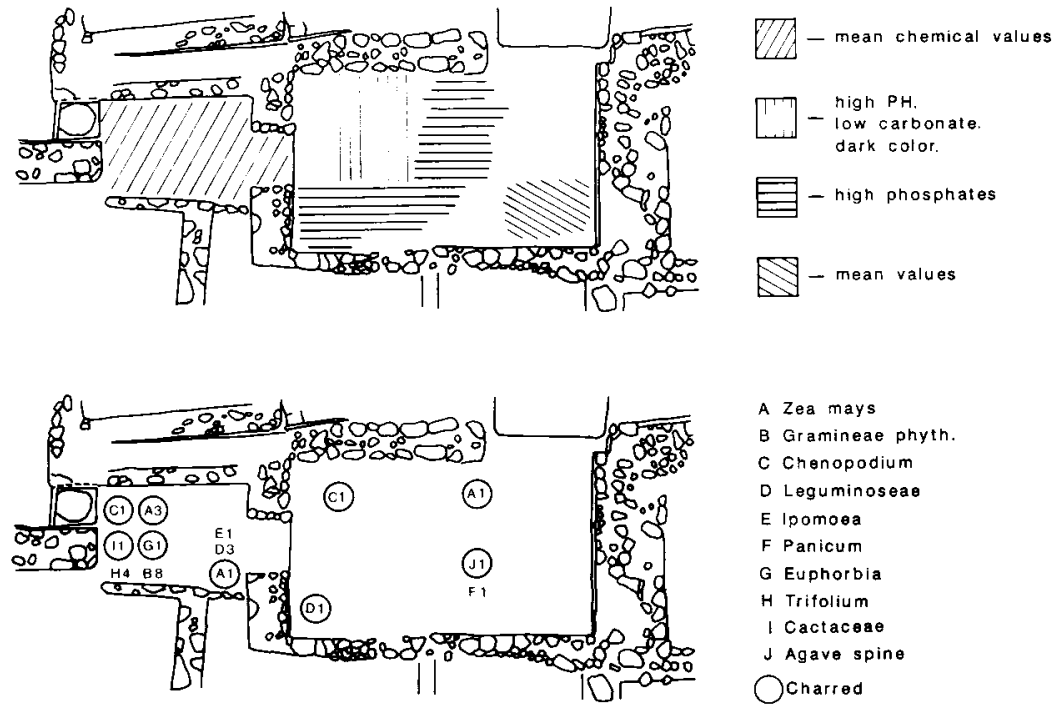

A Zea mays
B Gramineae phyth.
C Chonopodium
D Leguminoseae
E Ipomoea
F Panicum
G Euphorbia
H Trifolium
I Cactaceae
J Agave spine
OCharred

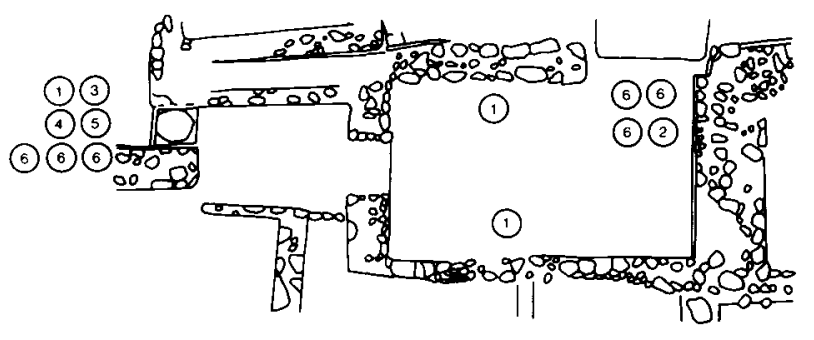
RABBITS:
1. Sylvilagus floridanus
2. Sylvilagus sp.
HARES:
3. Lopus mexicanus
4. Lepus sp.
FISH:
5. Telcostoo sp.
SNAILS:
6. Puimonata

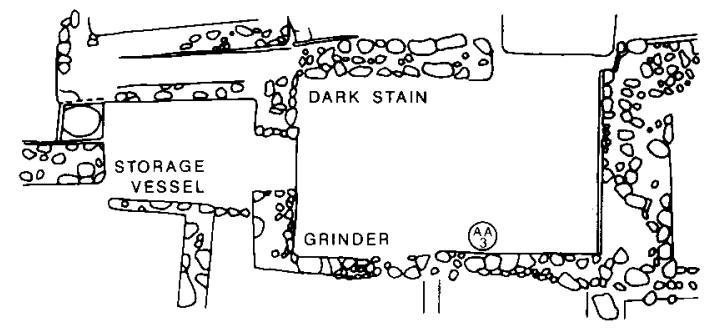

(AA) 8 Prismatic blades 1 Projectile point 2 Figurine heads 2 Beads

Figure 5. Rooms 5 and 3-4, with differential distributions of remains (chemical, paleobotanical, paleozoological, and archaeological).

slight phosphate increase-accords perfectly with an identification of the area as a place of storage.

The other storage sector (room C18) was a large room situated in the western portion of the compound. It had a depressed area where several storage vessels were found.

\section{Manufacture}

Only one sector had data related to lithic edge rejuvenation. This area was located in the corner of Room C9 and consisted of a concentration of 58 obsidian prismatic blade fragments, a basalt hammerstone, and a limestone anvil. The other activity that was profusely represented was plaster polishing. This could be detected in the northern sector of the compound, where some grave cuts in the plaster floor were apparently abandoned before being covered again with stucco. The lime mixture was already prepared, and a basalt polisher lay on top of it. There were more than thirty basalt polishers in our unit, thus providing a suggestion of probable group function.

\section{Cult Areas}

Cult areas were located in the northern and eastern rooms of the compound and were represented either by small round cavities in the floor, where offering vessels containing bird bones or plants were placed, or by the presence of the Fire God brazier and animal remains from neighboring regions: a bear, a puma fang, mother-of-pearl, and other marine shells (Spondylus calcifer), together with exogenous fresh water shells. This sector is also characterized by the presence of burials containing carbonized pinetree wood, maize, and marine shells. 
Other cult indicators were two sectional architectural models, one corresponding to a temple platform (found in C33) and the other to a frieze fragment (in C25). In both cases these were discovered in sunken courtyards surrounded by porticoes. The temple platform model served as base for a small rabbit sculpture, which probably formed part of either a lineage cult or an early pulque god cult (Manzanilla and Ortiz 1990).

\section{Butchering and Refuse Sector}

All the southern rooms had evidence of butchering; several rabbit and hare remains were found, along with high phosphate values. There was only one other context with similar information. In a corner of a Room C50, to the east of the service courtyard, were uncovered 12 obsidian blades near rabbit, rodent, and mollusk remains: these were accompanied by high phosphate and $\mathrm{pH}$ values.

In general, we can conclude that there was clear differentiation between the uses of the various sectors: in the south, the refuse areas; the central-south and central-east zones, areas for food preparation and consumption; the eastern sector for access and a domestic cult; the western sector for storage; the northern sector for burials, some in the process of being remodeled before the abandonment took place; the central portion probably for sleeping; and finally, the northwestern section, with the largest courtyard, probably the household's meeting place.

\section{FINAL REMARKS}

Both examples, one from Coba, the other from Teotihuacan, show that Classic households were formed by more than one nuclear family. Yet the Teotihuacan case displays more internal cohesion because of its particular residential patterns, its seclusion from external life, and the probable existence of common manufacture or construction activities beyond local needs.

Our structure was a small one (a fifth of Tetitla's area), and we can say with certainty that three families, perhaps a fourth one, were living there. This conclusion is drawn from our detection of three food-consumption areas. These families were further integrated by cult practices, some of which were at the group level (as in C41) and others apparently at a nuclear family level (as in C33 and C25).

One difference between the Maya and Teotihuacan domestic patterns is the existence in the former of domestic orchards, and the dispersion of activities in various constructions. Yet, despite such differences, we feel that chemical data have more than proven their usefulness. In the absence of clear evidence from artifacts or other indicators, chemical analysis of house floors show clear promise in elucidating activity areas.

\section{SUMARIO}

Los estudios de la vivienda son de creciente importancia para los arqueólogos mesoamericanos, quienes han empezado a concentrarse en las escalas más pequeñas de asentamiento. Pero esta investigación también ha sido distorsionada por la confusión que existe entre las áreas de actividad que functionalmente son distintas y por problemas con suposiciones discutibles y no probadas que se refieren al tamaño, la historia y la composición de la vivienda. Para tratar tales problemas, los especialistas han adoptado dos métodos, uno que se basa en la etnoarqueología, y otro que se basa en los estudios más convencionales de tipos de distrubución.

Este artículo añade una nueva dimensión al discutir concentraciones químicas relacionadas a las áreas de actividad. Tal análisis mejora los modos anteriores de abordar estos problemas porque es más sensible a las actividades que suelen dejar pocos vestigios, si es que dejan alguno, particularmente en los lugares que se abandonaban poco a poco. El artículo informa acerca de cómo tales métodos, los nuevos y los conven- cionales, se han aplicado a unidades domésticas bien definidas en dos localidades mesoamericanas: el sitio de la época clásica maya, Cobá, y la ciudad central mexicana, Teotihuacan. Las excavaciones de Cobá revelan un modelo consistente con "la hipótesis de crecimento familiar," aunque en este caso el crecimiento parece no haber acontecido dentro de una unidad única, sino con un grupo vecino. Las excavaciones en una estructura habitacional de la fase "Xolalpan" (ca. A.D. 550-660) en Teotihuacan mostraron que era posible definir dónde tenían lugar ciertas actividades, incluyendo las que se relacionaban con el consumo, el almacenaje, la fabricación, la carnicería, la deposición de basura y la veneración religiosa. En esta investigación comparativa las viviendas de Teotihuacan parecieron tener más cohesión interna que las unidades de Cobá, aunque ambas probablemente tenian más de una familia nuclear. Nuestra investigación confirmó la validez del empleo del análisis químico para valorar áreas de actividad.

\section{ACKNOWLEDGMENTS}

We thank the following people for their participation in particula aspects of our projects: Agustín Ortiz and Alejandro Tovalín for chemical studies; Raúl Valadez, Alicia Blanco, and Gerardo Villanueva for paleofaunal analysis; Luis Beltrán, Neusa Hidalgo, and Javier González for paleobotanical data; Beatriz Ludlow for information on pollen; Eliseo Linares and Guillermo Pérez for sampling; and the Graphic Department of the Institute of Anthropological Research of the Universidad Nacional Autónoma de México for their invaluable help.

\section{REFERENCES}

Ashmore, Wendy, and Richard R. Wilk

1988 Household and Community in the Mesoamerican Past. In Household and Community in the Mesoamerican Past, edited by Wendy Ashmore and Richard R. Wilk, pp. 1-27. University of New Mexico Press, Albuquerque.

Barba, Luis

1986 La química en el estudio de areas de actividad. In Unidades habitacionales mesoamericanas y sus areas de actividad, edited by

Linda Manzanilla, pp. 21-39. Serie Antropológica 76. Instituto de Investigaciones Antropológicas, Universidad Nacional Autónoma de México.

Barba, Luis, Beatriz Ludlow, Linda Manzanilla, and Raúl Valadez

1987 La vida doméstica en Teotihuacan: Un estudio interdisciplinario. In Ciencia y Desarrollo 77:21-32 C.O.N.A.C.Y.T., México. 
Barba, Luis, and Gregorio Bello

1978 Análisis de fosfatos en al piso de una casa habitada actualmente. Notas Antropológicas 24:188-193. Universidad Nacional Autónoma de México.

Barba, Luis, and Pierre Denis

1981 Actividades humanas y análisis químicos de los suelos: El caso de Osumacinta Viejo, Chiapas. XVII Mesa Redonda de la Sociedad Mexicana de Antropología 2:263-277.

Barba, Luis, and Linda Manzanilla

1987a Estudio de áreas de actividad. In Cobá, Quintana Roo. Análisis de Dos Unidades Habitacionales Mayas del Horizonte Clásico edited by Linda Manzanilla, pp. 69-115. Universidad Nacional Autónoma de México, México.

$1987 b$ Superficie/excavación: Un intento de predicción de rasgos arqueológicos desde la superficie en Oztoyohualco. Antropológicas 1:19-46. Instituto de Investigaciones Antropológicas, Universidad Nacional Autónoma de México, México.

Binford, Lewis

1983 People in their Lifespace. In In Pursuit of the Past: Decoding the Archaeological Record, edited by Lewis Binford, pp. 144-194. Thames and Hudson, London.

Eidt, Robert C.

1973 A Rapid Chemical Field Test for Archaeological Site Surveying. American Antiquity 38(2):206-210.

Flannery, Kent V. (editor)

1976 The Early Mesoamerican Village. Academic Press, New York

Goffer, Zvi

1980 Archaeological Chemistry: A Sourcebook on the Applications of Chemistry to Archaeology. John Wiley and Sons, London.

Hill, James $\mathrm{N}$.

1968 Broken K Pueblo: Patterns of Form and Function. In New Perspectives in Archaeology, edited by Sally R. Binford and Lewis R. Binford, pp. 102-192. Aldine-Athertone, Chicago.

Kent, Susan

1987 Understanding the Use of Space: An Ethnoarchaeological Approach. In Method and Theory for Activity Area Research. An Ethnoarchaeological Approach, edited by Susan Kent, pp. 1-60. Columbia University Press, New York

Manzanilla, Linda

1979 Comentarios en torno a un proceso histórico: La constitución de la sociedad urbana en Mesopotamia (cuarto milenio a.c.). Unpublished master's thesis, Escuela Nacional de Antropología e Historia.

1985 El sitio de Cuanalan, Estado de México, en el marco de las comunidades pre-urbanas del Valle de Teotihuacan. In Mésoamerica y el centro de México: Una antología, edited by Jesús Monjarás-Ruiz, Rosa Brambila, and Emma Pérez Rocha, pp. 133-175. Colección Biblioteca del Instituto Nacional de Antropología e Historia, Instituto Nacional de Antropología e Historia, México.

1986a Introducción. In Unidades habitacionales mesoamericanas y sus áreas de actividad (Serie Antropológica 76), edited by Linda Manzanilla, pp. 9-18. Arqueología, Instituto de Investigaciones Antropológicas, Universidad Nacional Autónoma de México. 1986b La constitución de la sociedad urbana en Mesopotamia: Un proceso en la historia. (Arqueología, Serie Antropológica 80), Instituto de Investigaciones Antropológicas, Universidad Nacional Autónoma de México.

1987 Coba, Quintana Roo. Análisis de dos unidades habitacionales mayas del Horizonte Clásico (Arqueología, Serie Antropológica 82). Instituto de Investigaciones Antropológicas, Universidad Nacional Autónoma de México.

Manzanilla, Linda, and Agustín Ortiz

1990 Los altares domésticos en Teotihuacan: Hallazgo de dos fragmentos de maqueta. Cuadernos de Arquitectura Mesoamericana, Facultad de Arquitectura, Universidad Nacional Autónoma de México, in press.

Mejía, Elizabeth

1987 Análisis químico de unidades habitacionales en el sitio de La Florida, Zacatecas. Unpublished master's thesis, Instituto Nacional de Antropologia e Historia, México.

Mejía, Elizabeth, and Luis Barba

1988 El análisis de fosfatos en la arqueología: Historia y perspectivas. Anales de Antropología, Universidad Nacional Autónoma de México.

Millon, Rene

1973 Urbanization at Teotihuacan, Mexico, Vol.1: The Teotihuacan Map. University of Texan Press, Austin.

Rathje, William L., and Michael B. Schiffer

1982 Archaeology. Harcourt, Brace Jovanovich. New York.

Reyna Robles, Rosa María

1977 Desarrollo y evolución de una "unidad habitacional" en una aldea preclásica del altiplano central: Loma Torremote como un ejemplo. Los procesos de cambio en Mesoamérica y áreas circunvecinas, XV Mesa Redonda 1:357-383. Sociedad Mexicana de Antropología, Guanajuato.

Serra, Mari Carmen

1980 La unidad habitacional en Terremote-Tlaltenco, D.F.: Un análisis de actividad, Primera parte. Anales de Antropología XVIII 1:167-186. Instituto de Investigaciones Antropológicas, Universidad Nacional Autónoma de México.

1986 Unidades habitacionales del Formativo en la Cuenca de Mexico." In Unidades habitacionales y sus áreas de actividad (Arqueología, Serie Antropológica 76), edited by Linda Manzanilla, pp. 161-192. Instituto de Investigaciones Antropológicas, Universidad Nacional Autónoma de México.

Seymour, Deni, and Michael Schiffer

1987 A Preliminary Analysis of Pithouse Assemblages from Snaketown, Arizona. In Method and Theory for Activity Area Research: An Ethnoarchaeological Approach, edited by Susan Kent, pp. 549-603. Columbia University Press, New York.

Tourtellot, Gair

1988 Developmental Cycles of Households and Houses at Seibal. In Household and Community in the Mesoamerican Past, edited by Richard R. Wilk and Wendy Ashmore, pp. 97-120. University of New Mexico Press, Albuquerque. 